\title{
An innovated integrated prefabricated quarter system for the migrant on-site construction workers of China
}

\author{
Tao WANG ${ }^{1 *}$, Yulong $\mathrm{LI}^{1}$, Guijun $\mathrm{LI}^{1}$, Sijia WU ${ }^{1}$ \\ ${ }^{1}$ Central University of Finance and Economics \\ *Corresponding author’s e-mail: wangtaothu@163.com
}

\begin{abstract}
Migrant construction workers from rural communities are the main workforce in the Chinese construction industry and urban development. While far from hometown, most migrant construction workers live in temporary quarters, with poor conditions, on or near the construction site. Although there are standards set by the government to guarantee the basic health and safety conditions of such housing, migrant construction workers in China suffer some of the worst living conditions, even compared to migrant workers in other industries. Health and safety accidents occur often enough in workers' quarters to provoke young laborers from rural areas to seek employment in the service industry, where better living conditions are available. As a result, serious labor shortages in the construction industry have emerged in China over recent years. There is a significant requirement for the industry to improve the condition of living quarters, by applying both technical and management methods. So far, very few articles have addressed the methods for improving the accommodations for rural migrant construction workers in urban China. This paper aims to develop an innovated integrated prefabricated (prefab) quarter system for the on-site construction workers in China. The paper first discusses the current status of the traditional construction workers' quarters to disclose the most urgent problems in need of resolution. Barriers that block the innovation of improved workers' quarters are listed. Then an innovated integrated prefab quarter system is introduced. The feasibility and applicability of the proposed system are discussed. The strengths of the system with regard to the management of health, safety, and environment are analyzed and compared to the traditional system. An actual pilot project is studied as the validation of the prefab quarter system.
\end{abstract}

KEYWORDS prefab quarter; rural migrant; construction; on site worker; accommodation; China; case study

\section{INTRODUCTION}

Since China's economic reform and opening up, migrant workers, who travel from rural areas and seek better employment opportunities in towns or cities in an effort to change their roles from farmers to industrial or service workers, have become a unique and burgeoning population (Tao, Wong, \& Hui, 2014). Construction, a labor-intensive industry (Agapiou, Price, \& McCaffer, 1995), is one of the pillar industries in China, and migrant workers in the construction industry make up a large portion (22.2\%) of total migrant workers (National Bureau of Statistics of China, 2014). Compared to migrant workers in other industries, migrant construction workers are subjected to demanding conditions such as working in the open-air environment, bearing intensive workloads, working long hours, and enduring poor working conditions. Since construction sites are typically far from migrant workers' hometowns, these employees usually 
reside in the temporary quarters that contractors build near or on the construction site to reduce commuting costs. These quarters are usually built prior to the construction of the main project structure and are removed at the end of the project, when the contractor leaves the site.

Since quarters for migrant construction workers are temporary buildings and free to use, standard living conditions for these workers are not only far below those of urban residents but also worse than those of migrant workers in other industries. Besides poor living conditions, there are many potential safety and health hazards. Multiple people living in one dorm room also raises difficulties in management. Poor living conditions can reduce worker satisfaction, lead to behaviors that jeopardize health and safety, and thus reduce the work efficiency of employees (Judge, Thoresen, Bono, \& Patton, 2001; Locke, 1970). Moreover, a series of social, health, and safety problems caused by poor worker accommodations has made the construction industry synonymous with "dirty, bitter, and tired," a sentiment that diminishes the reputation of the industry.

In recent years, investment in infrastructure in China has stimulated important economic growth, so the demand for construction workers has increased significantly. However, with the improvement of China's national income, the cost of human resources and payroll rises yearly. Meanwhile, the new generation of rural migrant workers, who were born in the 80s and 90s, are better educated than their elder generation (National Bureau of Statistics of China, 2014), and their requirements with regard to social status of work and level of income have become higher. Further, young migrant workers have a greater awareness of their rights of protection and enhanced welfare. Good accommodations, leisure activities, and even the opportunity for skills training have become increasingly important factors to migrant workers in choosing their jobs (Chen, Lin, \& Hsu, 2014). The new generation of the migrant workers are more inclined to engage in service industries rather than the "dirty, bitter, tired" construction industry, and this has created a shortage of on-site construction workers, a serious and chronic problem, both in developed and developing countries (Han, Park, Jin, Kim, \& Seong, 2008). Labor shortages plague the construction market in many large cities in China, even with significantly improved wages.

To ameliorate this situation, the social status of migrant workers in the construction industry must be elevated, and improving worker accommodations is a top priority in achieving this end. However, changing the deeply rooted traditional production mode to improve accommodations for migrant construction workers will be challenging, as investors and contractors operate under the condition of controlling costs. Although previous studies have discussed the problems of Chinese migrant workers' living conditions, system solutions have not been systematically proposed (Keung Wong, Li, \& Song, 2007; Ling, Dulaimi, \& Chua, 2013; Smith, 2003). This paper aims to develop an innovated integrated prefabricated (prefab) quarter system for the migrant on-site construction workers in China. The paper first examines the current traditional construction workers' quarters, analyzing inherent problems in health, safety, and environment (HSE). Then, our innovated integrated prefab quarter system will be introduced, both from a technical and management aspect. A real-world pilot project is studied as validation of the prefab quarter system, and we will explore the advantages of our integrated management model. The paper will then discuss the feasibility and business model of the proposed prefab quarter system, with regard to cost and management, as well as the prospects of its popularization.

\section{TRADITIONAL MIGRANT CONSTRUCTION WORKERS’ QUARTERS}

\section{Current situation and problems}


Traditional migrant construction workers' quarters are usually made of polystyrene board, color steel board, wood board, and steel frame, as shown in Figure 1. The applicable area of the quarters are approximately $12-30 \mathrm{~m}^{2}$, containing 3-8 bunk beds. Four to fifteen workers reside in one room, without mutual isolation, even between male and female workers, as shown in Figure 2. There are only shared toilets, and these bathrooms are situated outside of the quarters. To control cost, the quarters contain few furnishings and appliances such as chests, tables, chairs, televisions, refrigerators, etc. Only a few quarters are equipped with air conditioners in regions having hot summer temperatures.

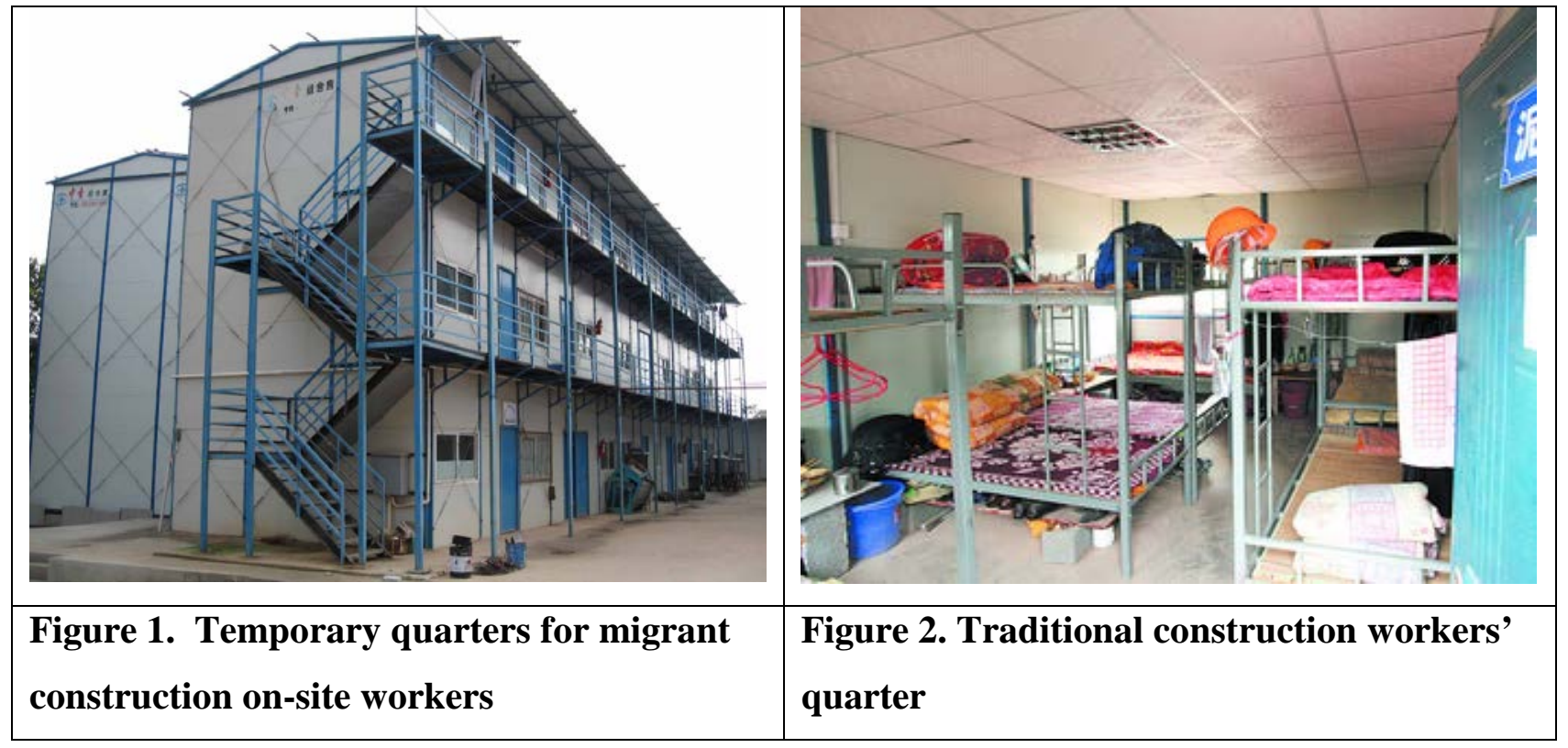

The high intensity work of construction is in sharp contrast with the low degree of comfortable habitation and conditions for rest. Decreasing numbers of new migrant workers opt to enter into the construction industry only to bear crowded accommodations, lack of personal privacy, lack of public health management, and inadequate household appliances. There are additional HSE problems in traditional migrant construction workers' quarters, which are summarized in Table 1. Poor accommodation and inferior conditions may result in physical and mental health problems in the workers. Both personal safety and property security are concerns for migrant workers in traditional quarters as temporary workers live a relatively rough lifestyle, which may lead to both natural and social environment problems. The huge gap between city life and life on the construction site may dissuade young migrant workers from joining the construction industry and lead them to seek what may seem a better lifestyle in the city. 
Table 1. Health, safety, and environmental problems in traditional migrant construction workers' quarters

\begin{tabular}{|c|c|c|c|}
\hline Problem & Level 1 & Level 2 & Problem Statement \\
\hline \multirow[t]{10}{*}{ Health } & \multirow[t]{6}{*}{$\begin{array}{l}\text { Physical } \\
\text { health }\end{array}$} & $\begin{array}{l}\text { Spread of } \\
\text { infectious } \\
\text { diseases }\end{array}$ & $\begin{array}{l}\text { More than } 4 \text { workers living in one room where the per capita living area is small, without separate toilet and bathroom. } \\
\text { Poor indoor air circulation can easily lead to the rapid spread of infectious diseases. }\end{array}$ \\
\hline & & Mosquito bites & $\begin{array}{l}\text { Poor environmental management around traditional construction workers' quarter can easily lead to the breeding of } \\
\text { mosquitoes }\end{array}$ \\
\hline & & $\begin{array}{l}\text { Temperature } \\
\text { changes }\end{array}$ & $\begin{array}{l}\text { Heat/insulation performance of traditional construction workers' quarters is poor. The traditional quarter is frequently } \\
\text { not equipped with air-conditioner. Indoor temperature in hot summers or cold winters is too high or too low, which } \\
\text { increases the risk of heatstroke or catarrh. }\end{array}$ \\
\hline & & Dust pollution & $\begin{array}{l}\text { Dirt and dust can be easily tracked into the dormitory as quarters are near the construction site, resulting in poor quality } \\
\text { of indoor air. }\end{array}$ \\
\hline & & $\begin{array}{l}\text { Mutual } \\
\text { interference }\end{array}$ & $\begin{array}{l}\text { With typically more than } 4 \text { workers in one room, workers interfere with each other and affect normal rest of others } \\
\text { because of personal activities, such as snoring, talking, using lighting, using the telephone, etc. }\end{array}$ \\
\hline & & Diet problem & $\begin{array}{l}\text { Providing basic food cannot meet the multilevel needs for all migrant workers. Unregulated food management can } \\
\text { introduce risk of food poisoning. }\end{array}$ \\
\hline & \multirow[t]{4}{*}{$\begin{array}{l}\text { Mental } \\
\text { health }\end{array}$} & Conflicts & $\begin{array}{l}\text { With typically more than } 4 \text { workers in one room, differences of individual characters and customs may cause } \\
\text { contradictions, conflicts, and unpleasant events among migrant workers. }\end{array}$ \\
\hline & & $\begin{array}{l}\text { Monotonous } \\
\text { life }\end{array}$ & $\begin{array}{l}\text { The per capita living area is small. Lack of infrastructure and leisure-time activities (culture, sports, and entertainment) } \\
\text { make workers' lives dull and boring. }\end{array}$ \\
\hline & & Privacy issues & $\begin{array}{l}\text { Crowded, with sometimes more than } 4 \text { strangers in a small room (even men and women together), there is no } \\
\text { individual private space. }\end{array}$ \\
\hline & & Insecurity & $\begin{array}{l}\text { Because of different professions and the transient nature of migrant work, individuals cannot build confidence with } \\
\text { each other in the short term. Thus, they are unable to foster a sense of social security. }\end{array}$ \\
\hline \multirow[t]{4}{*}{ Safety } & \multirow[t]{2}{*}{$\begin{array}{l}\text { Personal } \\
\text { safety }\end{array}$} & Fire safety & $\begin{array}{l}\text { The main construction materials of traditional construction workers' quarters are flammable polystyrene and wood. } \\
\text { Most contractors only meet the minimum legal requirements when constructing or using materials. Sometimes they do } \\
\text { not even meet these specifications. Smoking, using fire, re-wiring chaotically, and abusing personal electrical } \\
\text { appliances are apt to cause fires. }\end{array}$ \\
\hline & & $\begin{array}{l}\text { Residential } \\
\text { safety }\end{array}$ & $\begin{array}{l}\text { Ill-constructed bunk beds easily lead to accidental injury. The site fences and emergency escape routes of multilayer } \\
\text { movable buildings often do not meet specifications, which can cause potential safety problems. }\end{array}$ \\
\hline & \multirow[t]{2}{*}{$\begin{array}{l}\text { Property } \\
\text { security }\end{array}$} & $\begin{array}{l}\text { Personal } \\
\text { property } \\
\text { security }\end{array}$ & $\begin{array}{l}\text { Security measures of the traditional construction workers' quarter are imperfect and incomplete. Burglary is common, } \\
\text { resulting in loss of property. Keys to the rooms are hard to manage as there are more than } 4 \text { workers in a room. } \\
\text { Security systems are not perfect, which leaves workers at risk of losing property. }\end{array}$ \\
\hline & & $\begin{array}{l}\text { Public property } \\
\text { security }\end{array}$ & $\begin{array}{l}\text { As people live in groups for free, raucous behavior may lead to damaged or stolen public property during the time of } \\
\text { using public property. }\end{array}$ \\
\hline \multirow[t]{2}{*}{$\begin{array}{l}\text { Environ- } \\
\text { ment }\end{array}$} & \multirow[t]{2}{*}{$\begin{array}{l}\text { Natural } \\
\text { environ- } \\
\text { ment }\end{array}$} & $\begin{array}{l}\text { Material } \\
\text { contamination }\end{array}$ & $\begin{array}{l}\text { Materials of the traditional construction workers' quarter are mostly disposable. They have relatively high energy } \\
\text { consumption, low efficiency of recycling, and low recycling residuals that cause pollution and damage to the } \\
\text { environment. }\end{array}$ \\
\hline & & Life pollution & The management of traditional construction workers’ quarter is extensive and rough which can easily produce garbage \\
\hline
\end{tabular}




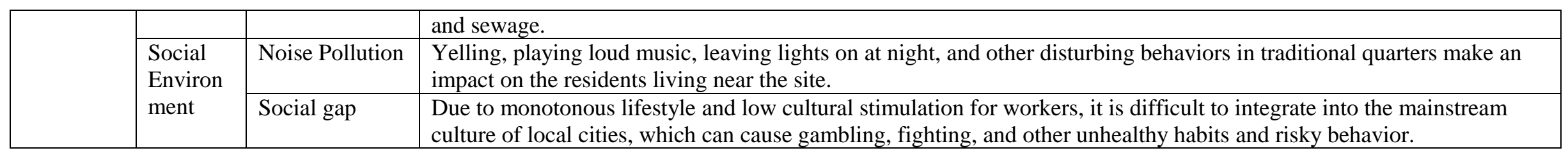

\section{Table 2. Barriers to improve the migrant construction workers' quarter conditions}

\begin{tabular}{|c|c|c|c|}
\hline \multicolumn{3}{|c|}{ Barriers } & Contents \\
\hline \multirow[t]{3}{*}{$\begin{array}{l}\text { Macro - } \\
\text { environment }\end{array}$} & \multirow[t]{2}{*}{ Government } & $\begin{array}{l}\text { Urban housing security } \\
\text { system }\end{array}$ & $\begin{array}{l}\text { The urban housing security system does not include the accommodations of migrant workers who } \\
\text { cannot benefit from affordable housing policies such as when buying affordable housing and renting } \\
\text { low-rent housing. }\end{array}$ \\
\hline & & Lagging standards & $\begin{array}{l}\text { The mandatory requirement set up by the government to ensure construction units provide the minimal } \\
\text { accommodation for migrant workers is lagging behind the social average growth of living standard. } \\
\text { Therefore, contractors have no incentive to improve living conditions for migrant workers. }\end{array}$ \\
\hline & Society & $\begin{array}{l}\text { The "city - rural" dual } \\
\text { social system in China }\end{array}$ & $\begin{array}{l}\text { There is a large difference between city residents and rural residents including social status, cultural } \\
\text { level, and customs. Migrant workers belong to a vulnerable group. It is more difficult for them to } \\
\text { integrate into society or put forward higher demands for living conditions. Society can easily ignore } \\
\text { living conditions of migrant workers. }\end{array}$ \\
\hline \multirow[t]{8}{*}{$\begin{array}{l}\text { Micro - } \\
\text { environment }\end{array}$} & \multirow[t]{3}{*}{$\begin{array}{l}\text { Construction } \\
\text { units }\end{array}$} & Cost control & $\begin{array}{l}\text { In the current situation of providing free accommodations, meeting government's minimum mandatory } \\
\text { requirements is enough for construction companies and contractors. There is no incentives to increase } \\
\text { quality and cost of quarters. }\end{array}$ \\
\hline & & Mobility of workers & $\begin{array}{l}\text { Because of the high turnover of migrant workers throughout projects, construction companies and } \\
\text { contractors do not want to invest too much. }\end{array}$ \\
\hline & & Disposable investment & $\begin{array}{l}\text { General construction periods of projects are short, about 1.5-3 years. The turnover time of prefab } \\
\text { houses is low, generally two or three times. It is difficult to improve disposable investments; therefore, } \\
\text { living conditions and hardware are at a low level. }\end{array}$ \\
\hline & \multirow{5}{*}{$\begin{array}{l}\text { Migrant } \\
\text { workers }\end{array}$} & Awareness of rights & Migrant workers lack the awareness of maintaining legal rights. \\
\hline & & Social status & $\begin{array}{l}\text { Although the number of migrant workers is large, with weak social status and loose organization, they } \\
\text { do not form unions. In fact, they are not included in the national security system. }\end{array}$ \\
\hline & & Income restrictions & $\begin{array}{l}\text { The social security system is not perfect for migrant workers; they are concern with absolute income in } \\
\text { the short term and strive to save money. To save more money, they minimize spending; particularly, } \\
\text { they are reluctant to spend large amounts of wages on rent. }\end{array}$ \\
\hline & & Single option & $\begin{array}{l}\text { Migrant workers have no choice in selecting accommodation; in fact, construction sites do not provide } \\
\text { multilevel accommodations. }\end{array}$ \\
\hline & & Expectation & $\begin{array}{l}\text { As migrant workers are from rural areas, their expectations for living conditions are low, as long as } \\
\text { living condition meet their basic living security. They are not compelled to take the initiative to seek } \\
\text { better conditions. }\end{array}$ \\
\hline
\end{tabular}




\section{Barriers to improve the conditions}

Although the poor accommodation conditions of migrant construction workers may result in many problems, it is not easy to improve the condition of workers' quarters. There are a series of barriers stemming from the government, issues of societal status, the construction market, and workers themselves, as outlined in Table 2. The elder generation of migrant construction workers from rural areas were typically already living in poor conditions in their communities. Their expectations for construction site accommodations was relatively low. They usual lacked the awareness of their rights and were not willing to strive for higher quality accommodations. Therefore, the government, society, and various enterprises paid little attention to this special group of the people. However, the situation is changing, along with the development of the societal opening and economic growth as discussed in the Introduction. Migrant workers earn higher income, are more educated, and easily obtain information with the popularity of the Internet and the development of society. The barriers listed in Table 2 are breaking down, especially those barriers pertaining to workers themselves. The changing background of the labor market are calling for a better quarter system for the migrant construction workers.

\section{INNOVATED INTEGRATED PREFAB QUARTER SYSTEM}

The integrated prefab quarter system is not only a new quarter design, which is similar to the prefab container dormitory that already exists on the market, but it also includes a practical management mode. The researchers strived to establish a new business mode to progress beyond

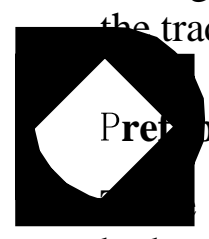

raditional mode, which is ineffective, using superficial form modification.

\section{quarters}

are two standard quarter types for workers, as shown in Figure 3. Type $a$ has two single beds serving two workers in one room. The workers can put their belongings on the upper bed and sleep on the lower bed. Type $b$ has a double bed and a desk serving double workers (husband and wife) or foreman who needs better accommodation. Both type $a$ and type $b$ are equipped with private toilet, bathroom, water heater, and air-conditioner. The doors of the quarters are equipped with smart card locks to ensure the security of the quarter. The quarters are made of colored steel plates, which complies with national standards of fire protection performance. To save space in the field site, quarters are installed as double-deck, as shown in Figure 4.

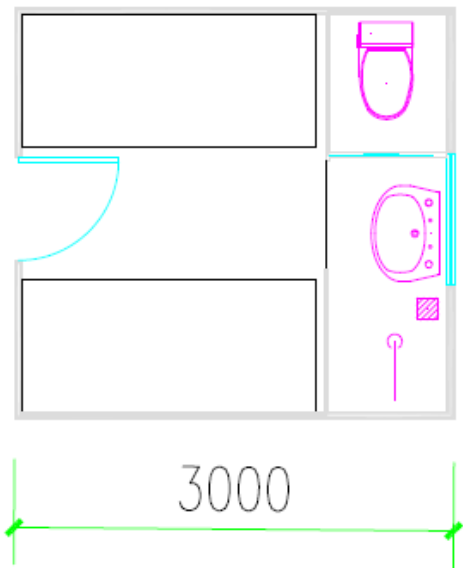

(a)
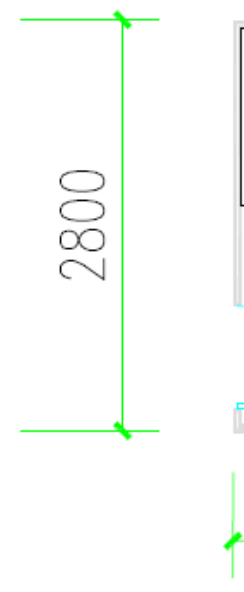

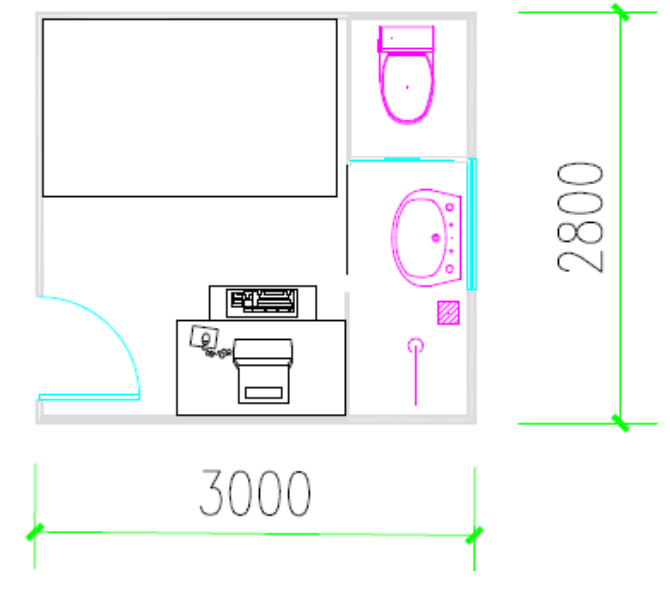

(b)

Figure 3. Temporary quarters for migrant construction on-site workers 


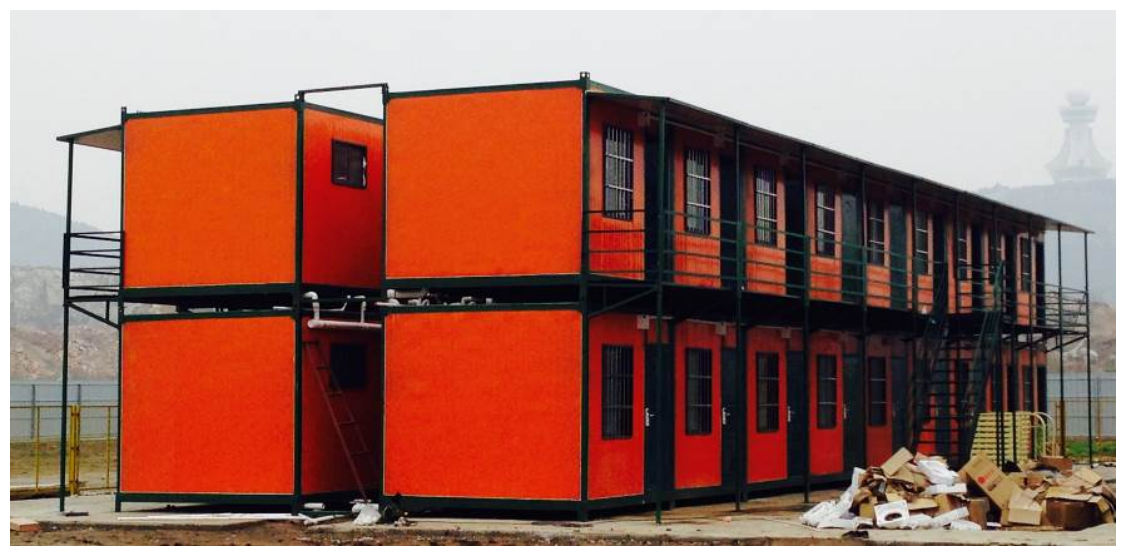

Figure 4. Double deck quarters on site (half finished)

\section{Management mode}

A new business mode is set up for the integrated prefab quarters, as shown in Figure 5. The traditional migrant construction workers' quarters are constructed by the general contractor, while the costs are charged from the direct project costs as a temporary facilities fee, typically consuming $1 \%-2.2 \%$ of the direct project costs. The investor or developer pays the fee to the general contractor whose logistics department is responsible for the accommodation and catering services of the migrant workers. A number of subcontractors including those involved in project preparation, earthwork, main structure, equipment and decoration, and finishing work all participate in the required services for the accommodation services; however, in the traditional business mode, the general contractor usually provides these tasks to subcontractors directly belonging to them. Subcontract workers such as those involved in project preparation and earthwork live in simple shacks and bear extremely primitive living conditions, as presented in Figure 6. The traditional quarters are usually free for use by workers of the general contractor and the contractors own subcontractors. This leads to filthy, unhygienic, uncomfortable conditions. The specialist subcontractors directly hired by the owners also have to rent the uncomfortable temporary quarters from the general contractor. This irregular field quarters management mode leads to many problems, as discussed in Table 1.

In the new system, integrated prefab quarters and support services are provided by a professional management agency. The subcontractors propose various requirements for the quantity of quarters needed. Then the investor or developer sort out all requirements and buy the accommodations, catering, and field management services from the professional management agency. The cost includes a temporary facilities fee, which is listed in the budget of the project. Unlike the traditional mode, migrant workers are charged reasonable fees to cover the incremental cost for higher quality quarters, with improved living standards, and they can enjoy clean accommodations, sanitary conditions, and adequate services. This is quite acceptable for the new generation of the migrant workers. Another reason for asking the workers to pay small fees for the service is to foster a culture of buying better accommodation service in the construction industry.

In the integrated prefab quarter system, the dormitory will be intelligently managed. Each worker will be equipped with a unique smart card, which can provide access to the quarter's field and into his or her room. The new management mode not only effectively ensures the security of workers' property but also maintains a clean environment of the quarters. An integrated management agency can facilitate rational organization of services for migrant workers by collecting data from construction workers' smart cards, such as food service choices, commodity demands, actual working hours of different professional workers, etc.

Competition can be introduced in food service availability on site. On the basis of health 
standards, dining rooms will have to strive to provide high-quality service and diverse cuisine, focusing on nutrition and health. Convenience stores, training, and entertainment services are also provided in the quarter's filed. The diversified services for migrant workers, whose consumption capacity was previously ignored, can also increase the profits for management agencies as a result of improved income and changing consumption behavior of this new generation of migrant workers. Based on the expense calendar of smart cards, the management agency can also adjust food service and entertainment service for workers to provide a continuously improving management services.

Another advantage of the integrated prefab quarter system is that the professional management agency can adjust the quantity of the quarters on site according to the actual requirements of the construction site. The management agency can increase the usage rate of the quarters by allocating quarters to multiple projects at different phases of each project, as shown in Figure 6. The sub-contractors will also satisfy the business mode because they can get rid of the constraint from the general contractor and get better accommodation service.

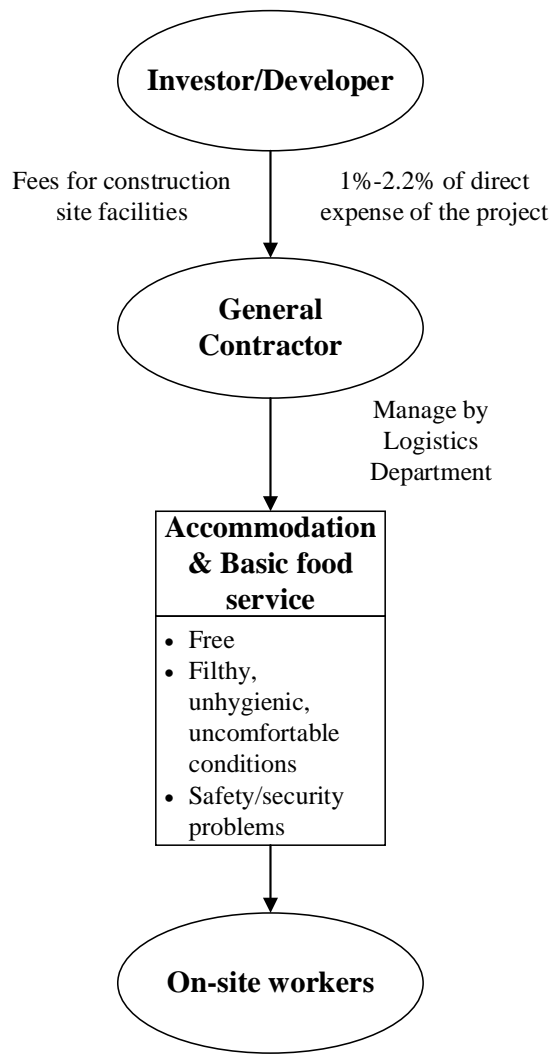

a. traditional construction workers’ quarter

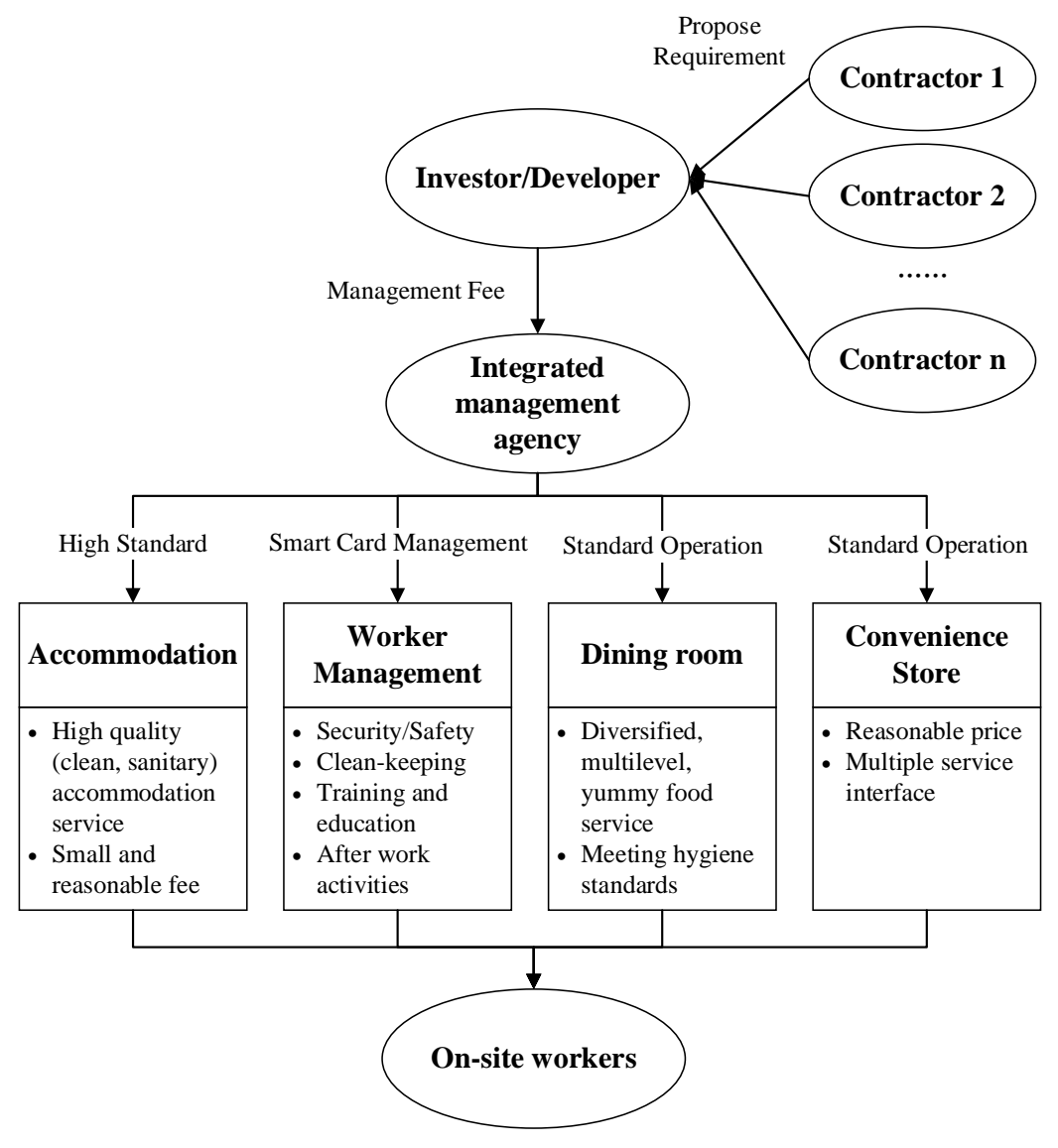

b. integrated prefab quarter system

Figure 5. Management mode of traditional construction workers' quarter and integrated prefab quarter system 


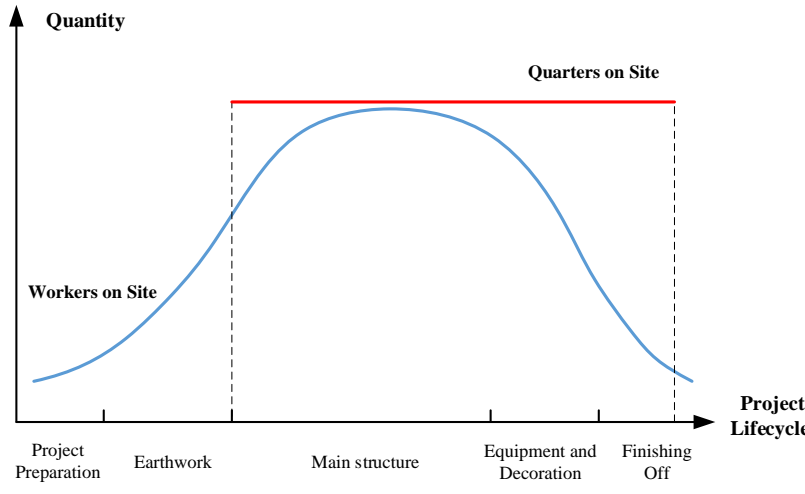

a. traditional construction workers' quarter

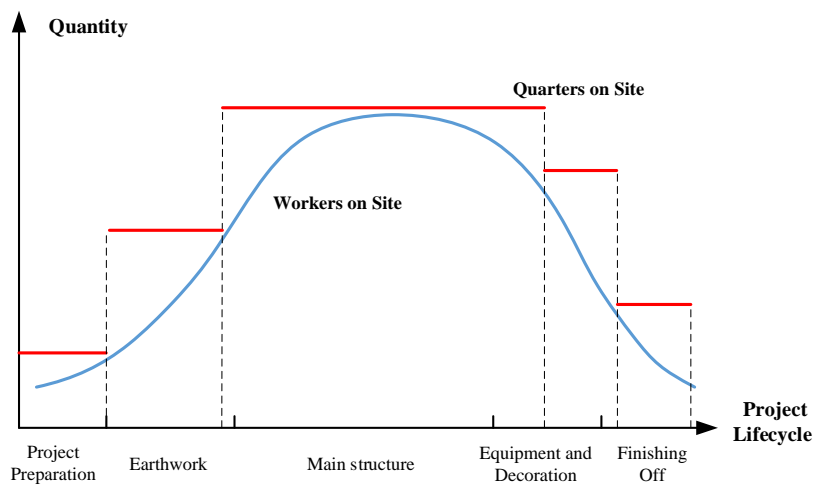

b. integrated prefab quarter system

Figure 6. Management mode of traditional construction workers' quarter and the integrated prefab quarter system

\section{Advantages of the system}

The integrated prefab quarter system employs a professional integrated management agency whose organization is well-regulated and institution is rounded. The new quarter not only provides comfortable living conditions but also ensures safety, security, and diversified food options. Also, it addresses the psychological well-being of migrant workers, far from home. There are leisure-time activities and skills training, which can abate the previously monotonous lifestyle of these workers. The emergency escape routes, fencing, and smart card security system are well designed to protect the property and personal security of workers. Meanwhile, there are additional HSE advantages of the integrated prefab quarter system, which are summarized in Table 3.

Table 3. Advantages of integrated prefab quarter system

\begin{tabular}{|c|c|c|c|}
\hline Problem & Level 1 & Level 2 & Advantages \\
\hline \multirow[t]{10}{*}{ Health } & \multirow[t]{6}{*}{$\begin{array}{l}\text { Physical } \\
\text { health }\end{array}$} & $\begin{array}{l}\text { Spread of } \\
\text { infection } \\
\text { diseases }\end{array}$ & $\begin{array}{l}1 \text { or } 2 \text { workers living in one room where the per capita living area increases, } \\
\text { with private toilet and bathroom. Also, better indoor air circulation can } \\
\text { effectively stop the spread of infection diseases. }\end{array}$ \\
\hline & & $\begin{array}{l}\text { Mosquito } \\
\text { bites }\end{array}$ & $\begin{array}{l}\text { Private toilet and bathroom keeps quarters clean and reduce mosquito } \\
\text { population. More private living environment can also help workers maintain } \\
\text { improved personal hygiene. }\end{array}$ \\
\hline & & $\begin{array}{l}\text { Temperature } \\
\text { changes }\end{array}$ & $\begin{array}{l}\text { Heat/insulation performance of new material is improved. Air-conditioning } \\
\text { makes indoor temperature more comfortable. }\end{array}$ \\
\hline & & Dust pollution & $\begin{array}{l}\text { Quarters are easier to keep clean, creating a better indoor environment, with } \\
\text { reduced dust pollution and significantly improved air quality. }\end{array}$ \\
\hline & & \begin{tabular}{|l} 
Mutual \\
interference
\end{tabular} & $\begin{array}{l}\text { As } 1 \text { or } 2 \text { workers live in one room, there is not much interference, which can } \\
\text { improve the quality of rest. }\end{array}$ \\
\hline & & Diet problem & $\begin{array}{l}\text { Integrated prefab quarter system provides basic and diverse food, which can } \\
\text { guarantee food safety and quality. }\end{array}$ \\
\hline & \multirow[t]{4}{*}{$\begin{array}{l}\text { Mental } \\
\text { health }\end{array}$} & Conflicts & $\begin{array}{l}1 \text { or } 2 \text { workers live in the traditional construction workers' quarter. } \\
\text { Contradictions, conflicts, and unpleasant events can be effectively avoided. }\end{array}$ \\
\hline & & $\begin{array}{l}\text { Monotonous } \\
\text { life }\end{array}$ & $\begin{array}{l}\text { Infrastructures and leisure-time activities (culture, sports, and entertainment) } \\
\text { are diversified, which enriches workers' spare time after work hours. }\end{array}$ \\
\hline & & Privacy issues & $\begin{array}{l}1 \text { or } 2 \text { workers living in a room can improve the privacy of the workers, } \\
\text { especially for the couple workers (husband and wife). }\end{array}$ \\
\hline & & Insecurity & $\begin{array}{l}\text { Smart card system is not only used at the entrance of the quarter site to prevent } \\
\text { the free flow of people without fixed duties and stop criminals but also at every }\end{array}$ \\
\hline
\end{tabular}




\begin{tabular}{|c|c|c|c|}
\hline & & & door of the quarter to guarantee personal safety and security. \\
\hline \multirow[t]{4}{*}{ Safety } & \multirow[t]{2}{*}{$\begin{array}{l}\text { Personal } \\
\text { safety }\end{array}$} & Fire safety & $\begin{array}{l}\text { The main materials of the integrated prefab quarter use fire prevention materials } \\
\text { and meet the fire prevention national standard. }\end{array}$ \\
\hline & & $\begin{array}{l}\text { Residential } \\
\text { safety }\end{array}$ & $\begin{array}{l}\text { Furnishings (as bunk beds) are standardized. Fences and emergency escape } \\
\text { routes of multilayer, movable houses meet national standard. Security system } \\
\text { with monitoring services and entrance guards could prevent potential accidents } \\
\text { and safety risk. }\end{array}$ \\
\hline & \multirow[t]{2}{*}{$\begin{array}{l}\text { Property } \\
\text { security }\end{array}$} & $\begin{array}{l}\text { Personal } \\
\text { property } \\
\text { security }\end{array}$ & $\begin{array}{l}\text { Smart card system can effectively prevent burglary within the transient } \\
\text { environment of the migrant workers. Every worker will be distributed a unique } \\
\text { identification and be managed in the smart system. }\end{array}$ \\
\hline & & \begin{tabular}{|l|} 
Public \\
property \\
security
\end{tabular} & $\begin{array}{l}\text { Due to the smart card system (installed on the door of every room) and standard } \\
\text { quarter management, raucous activity such as damaging or stealing public } \\
\text { property can be eradicated. }\end{array}$ \\
\hline \multirow[t]{4}{*}{$\begin{array}{l}\text { Environ- } \\
\text { ment }\end{array}$} & \multirow{2}{*}{$\begin{array}{l}\text { Natural } \\
\text { environ } \\
\text { ment }\end{array}$} & $\begin{array}{l}\text { Material } \\
\text { contamination }\end{array}$ & $\begin{array}{l}\text { Material use is economized by increasing turnovers in the life cycle of the } \\
\text { quarters. }\end{array}$ \\
\hline & & Life pollution & $\begin{array}{l}\text { The unit management of the quarter site has strict demands on disposing } \\
\text { garbage, which prevents the pollution on environment. }\end{array}$ \\
\hline & \multirow{2}{*}{$\begin{array}{l}\text { Social } \\
\text { environ } \\
\text { ment }\end{array}$} & $\begin{array}{l}\text { Noise } \\
\text { pollution }\end{array}$ & $\begin{array}{l}\text { Leisure-time activities and training for the workers could reduce the influence } \\
\text { on the surrounding residents. Private rooms could reduce noisiness. }\end{array}$ \\
\hline & & Social gap & $\begin{array}{l}\text { Quality training can engage migrant workers and help them integrate into city } \\
\text { life. Better lifestyle can also change the views of residents and narrow the gap } \\
\text { between citizens and migrant workers. }\end{array}$ \\
\hline
\end{tabular}

\section{FEASIBILITY AND APPLICABILITY OF THE INNOVATED SYSTEM}

As discussed above, the integrated prefab quarter system, equipped with quality appliances, and with innovated management could greatly improve the living conditions of migrant workers. An integrated professional management agency is introduced as the business mode. The $1 \%-2.2 \%$ of direct expense of the project in the traditional mode for temporary facilities are paid to the professional agency. However, it is critical to understand the economics evaluation performance of running the business. How much should the investor/developer pay for the integrated prefab quarter system? Does a comfortable living condition cost too much? Can the professional agency get enough profit to start the new business? A case of a real-world pilot project in Xuzhou, a city of Jiangsu province of China, was studied to evaluate the feasibility and applicability of the innovated integrated prefab quarter system. The project provides practical and real data to validate the economic feasibility of the system.

The project provides 200 quarters with auxiliary service rooms for about 400 workers on an $110,000 \mathrm{~m}^{2}$ apartment project. The costs of innovated integrated prefab quarters are listed and calculated in Table 4. The costs of traditional quarters for 400 workers on site are also estimated and analyzed and are presented in Table 5. The average accommodation cost for a worker per year is 1639 Yuan in the integrated prefab quarter, and 1165 Yuan in traditional quarters. A difference of 474 Yuan per year, which means about 1.5 Yuan per day, yields much more comfortable accommodations, with lower residential density, private bathrooms, air conditioning, multiple level optional food service, and a cleaner and safer lifestyle. The average income of a migrant construction worker is 200 Yuan per day. The incremental cost for the worker is less than $1 \%$. 
Table 4 Costs of innovated integrated prefab quarters for 400 workers on site

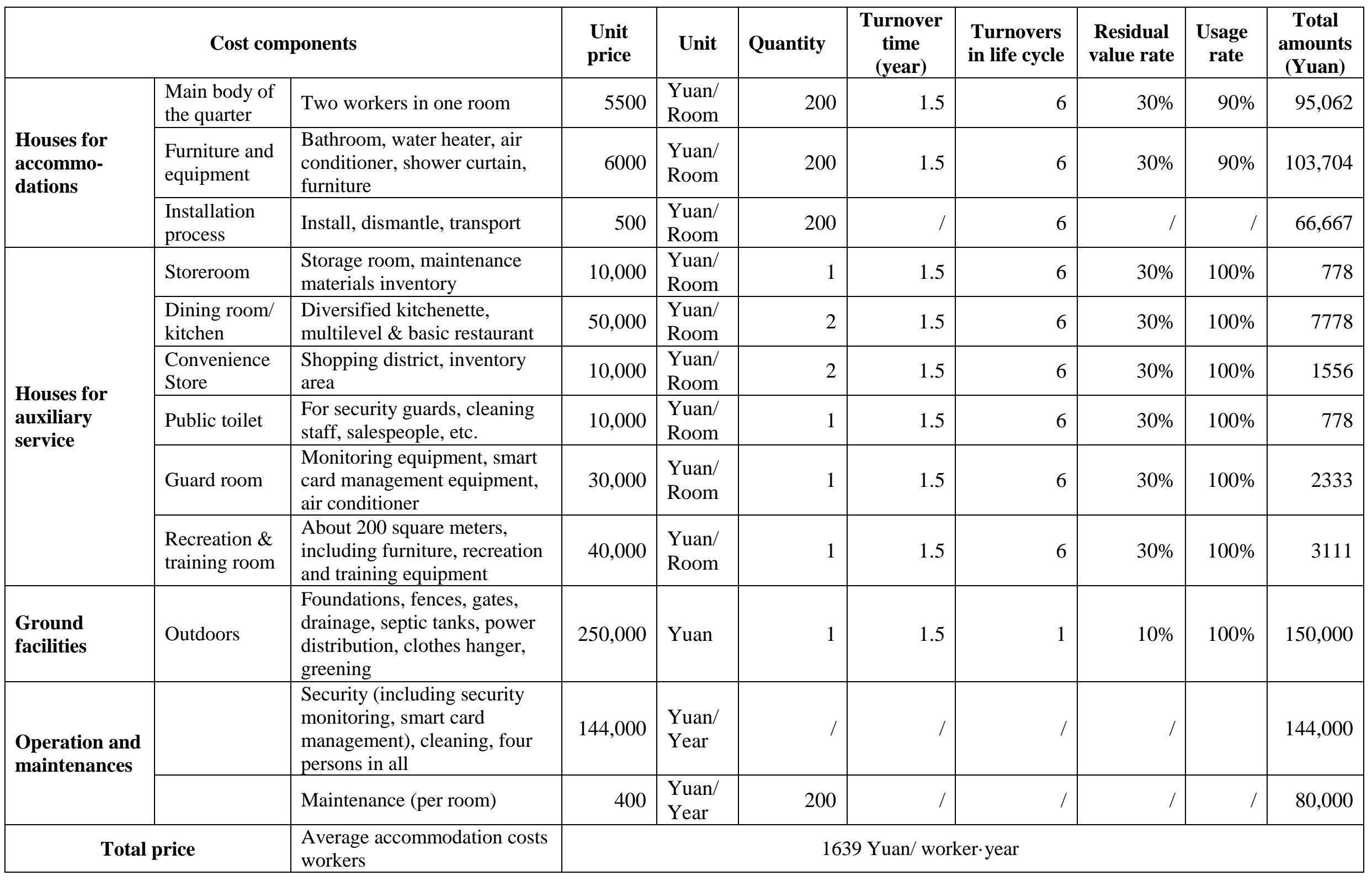


Table 5 Costs of traditional quarters for 400 workers on site

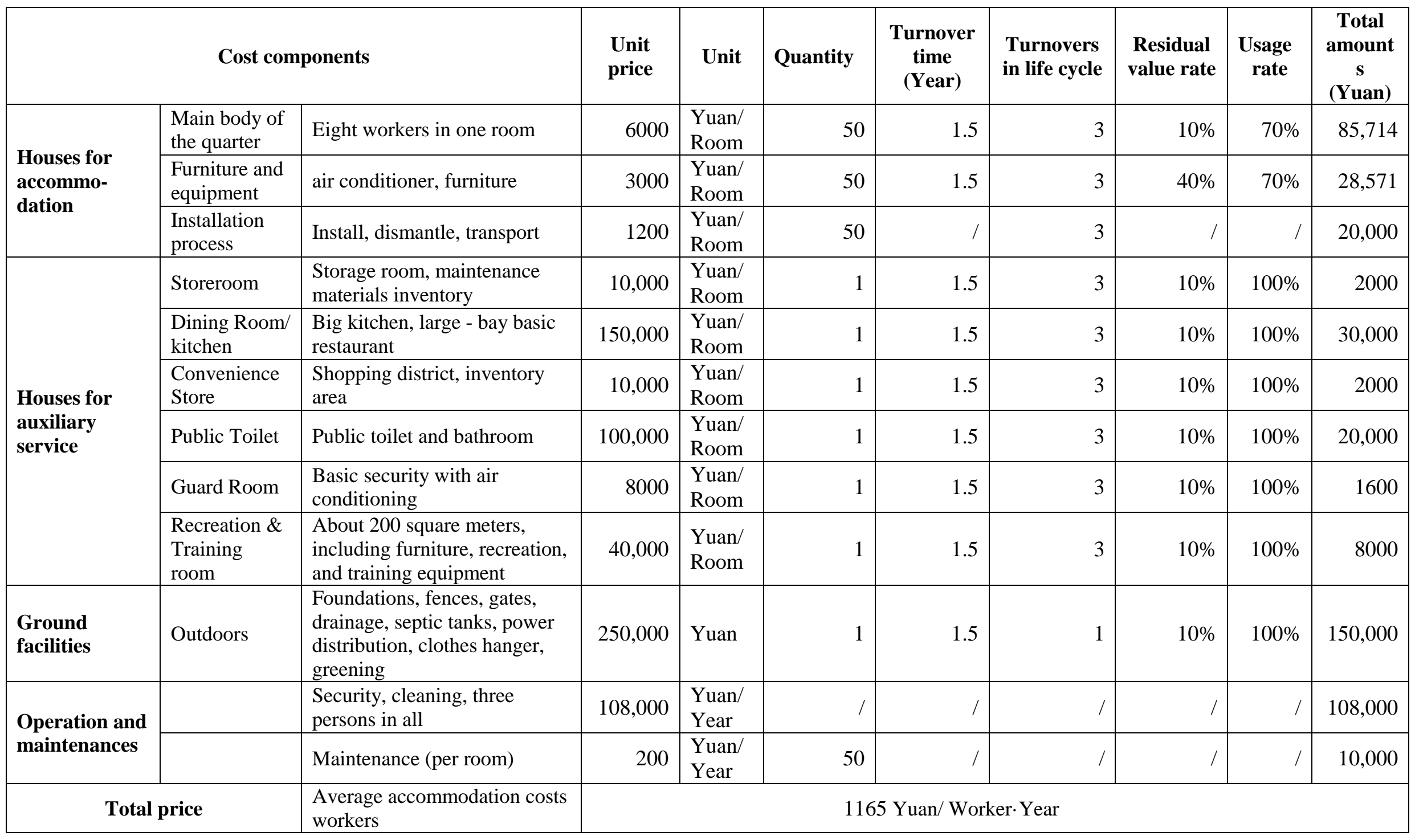


For the investor or developer, about 41\% (474/1165) cost is added for the temporary facilities, which accounts for $1 \%-2.2 \%$ of the direct expense of the project. This means less than $1 \%$ incremental cost of the direct expense of the project could bring migrant on-site construction workers a more comfortable accommodation, which could increase their productivity (Judge et al., 2001; Locke, 1970). Meanwhile, the innovated integrated prefab quarter system could also decrease the potential cost in safety and security losses, transfer the management responsibility to a professional agency, attract new young workers, and enhance the corporate image of the construction industry by strengthening the enterprise of social responsibility. The comprehensive benefit may cover the incremental cost of the new quarter system, or even generate profit on the whole.

For the government and society, the integrated prefab quarter system could economize material use by increasing turnover in the life cycle of quarters. The new business mode could adjust the structure of employment to satisfy the continuous infrastructure investment in the future and accelerate the urbanization process by enticing migrant workers from rural areas to live a city lifestyle.

Altogether, the integrated prefab quarter system is feasible and quite beneficial for workers, investors/developers, and the government/society. The case study of the pilot project shows promising application for the new quarter system.

\section{CONCLUSIONS}

This paper introduces an integrated prefab quarter system for the migrant on-site construction workers of China. The new workers' quarters could bring much more comfortable accommodations and living conditions, with lower residential density; private bathrooms; air conditioning; multiple level optional food service; and a cleaner, safer, and higher-quality lifestyle. The system has many advantages with regard to HSE compared to the traditional onsite construction workers' quarters. A case study of a real-world pilot project validates the economic feasibility and applicability of the innovated system. Future studies will focus on the promotion feasibility of the quarter system to nationwide construction sites. As the economic development levels of different areas of China are not quite balanced, there could be multilevel standard worker quarter services (such as a service classification indicated by stars) to meet the different requirements of workers in different regions of the country or for workers with different professions (who have different levels of income). Moreover, it is also a challenge for the professional agency who provides the integrated prefab quarter system to expand the business operations due to the relatively high initial investment for the quarters and the appliances.

\section{ACKNOWLEDGMENTS}

We wish to acknowledge the Natural Science Foundation of China (Grant No. 71401191, 71402200) and the 121 Youth PhD Development Foundation of CUFE (Grant No. QBJ1411) for funding this research.

\section{REFERENCES}

Agapiou, Andrew, Price, Andrew D. F., \& McCaffer, Ron. (1995). Planning future construction skill requirements: understanding labour resource issues. Construction Management and Economics, 13(2), 149-161. doi: 10.1080/01446199500000017 
Chen, J., Lin, J., \& Hsu, S. (2014). Determining and Classifying Factors of Employees’ Expatriation Willingness Using Rough Set Theory. Journal of Management in Engineering, 30(5), 04014021. doi: doi:10.1061/(ASCE)ME.1943-5479.0000206

Han, S., Park, S., Jin, E., Kim, H., \& Seong, Y. (2008). Critical Issues and Possible Solutions for Motivating Foreign Construction Workers. Journal of Management in Engineering, 24(4), 217-226. doi: doi:10.1061/(ASCE)0742-597X(2008)24:4(217)

Judge, Timothy A., Thoresen, Carl J., Bono, Joyce E., \& Patton, Gregory K. (2001). The job satisfaction-job performance relationship: A qualitative and quantitative review. Psychological Bulletin, 127(3), 376-407. doi: 10.1037/0033-2909.127.3.376

Keung Wong, Daniel Fu, Li, Chang Ying, \& Song, He Xue. (2007). Rural migrant workers in urban China: living a marginalised life. International Journal of Social Welfare, 16(1), 3240. doi: 10.1111/j.1468-2397.2007.00475.x

Ling, F., Dulaimi, M., \& Chua, M. (2013). Strategies for Managing Migrant Construction Workers from China, India, and the Philippines. Journal of Professional Issues in Engineering Education and Practice, 139(1), 19-26. doi: doi:10.1061/(ASCE)EI.1943-5541.0000124

Locke, Edwin A. (1970). Job satisfaction and job performance: A theoretical analysis. Organizational Behavior and Human Performance, 5(5), 484-500. doi: http://dx.doi.org/10.1016/0030-5073(70)90036-X

National Bureau of Statistics of China. (2014). Monitoring Survey Report on Migrant Workers in 2013: National Bureau of Statistics of China.

Smith, Chris. (2003). Living at Work: Management Control and the Dormitory Labour System in China. Asia Pacific Journal of Management, 20(3), 333-358. doi: 10.1023/A:1024097432726

Tao, Li, Wong, Francis K. W., \& Hui, Eddie C. M. (2014). Residential satisfaction of migrant workers in China: A case study of Shenzhen. Habitat International, 42(0), 193-202. doi: http://dx.doi.org/10.1016/j.habitatint.2013.12.006 